\title{
Firms' excess savings and the Dutch current-account surplus: a stock-flow consistent approach
}

\author{
Huub Meijers \\ Department of Economics, SBE, Maastricht University and UNU-MERIT, Maastricht, The Netherlands \\ Joan Muysken* \\ Department of Economics, SBE, Maastricht University, CofFEE Europe and UNU-MERIT, Maastricht, \\ The Netherlands

\section{Olaf Sleijpen} \\ Department of Economics, SBE, Maastricht University, Maastricht and De Nederlandsche Bank, Amsterdam, \\ The Netherlands
}

\begin{abstract}
Retained profits of firms exceed investment in the Netherlands. The resulting net savings are mainly invested in foreign assets, which is consistent with the surplus on the current account of the balance of payments. Both have increased to almost 10 per cent of GDP in recent years. We present a stock-flow consistent model to explain firms' excess savings, inspired by Hein (2012), in an open economy context. This enables us to model the preference of firms to invest in financial assets abroad and to analyse the observed close link between firms' excess savings and the current-account surplus. As a consequence, we also explain the close relationship between net household savings and government budget deficit. We present simulation results to illustrate the workings of our model.
\end{abstract}

Keywords: stock-flow consistent modelling, retained profits, current-account surplus

JEL codes: $E 44, E 6, F 45, G 32$

\section{INTRODUCTION}

A quite recent widely observed phenomenon is that firms' savings - that is, retained profits exceed investment at the national level. This holds in particular for large firms. This phenomenon is very visible in the Netherlands, where firms' savings increased from just above 10 per cent of GDP in the early 1990s to above 20 per cent in 2012, while firms' capital formation declined from around 13 per cent of GDP in the early 1990s to around 10 per cent in 2012. The resulting net savings are mainly held abroad. Moreover, there is a striking similarity in the development over time of net savings of firms on the one hand and the surplus on the current account on the balance of payments on the other. Both have increased to almost 10 per cent of GDP in recent years.

* Corresponding author: j.muysken@maastrichtuniversity.nl. We would like to thank the unknown referee for very useful comments.

Received 7 March 2016, accepted 20 June 2016 
Typical explanations for this phenomenon are that Dutch firms retain an extraordinarily high amount of profits, partly induced by tax motivations, and that investing in financial assets (abroad) generates a higher return than investing in 'capital' (non-financial assets). Since the majority of retained profits is invested in take-overs and financial assets abroad, this enables the foreign sector through various channels to borrow sufficient money to finance their net imports.

Traditional macroeconomic models cannot analyse this phenomenon since they lack a proper model of the financial sector and underestimate the potential for interactions between the monetary and the real sphere (Muysken 2014). Hein (2012) presents an interesting stock-flow consistent model of the firm to explain firms' excess savings, which is a valuable alternative to traditional and new Keynesian macroeconomic models. However, Hein's is a closed economy model without government. As a consequence the model does not explain (i) the preference of firms to invest in financial assets abroad, nor does it analyse (ii) the close link between firms' excess savings and the current-account surplus or (iii) the close link between net household savings and government budget deficit. For that reason we embed Hein's model of firm behaviour in a more elaborate stock-flow consistent model.

We have developed an open economy stock-flow consistent model, with a separate banking sector and government, in Meijers et al. (2015a) - MMS1 from hereon. In this paper we show how adding Hein's model of firm behaviour to that model enables us to explain the abovementioned phenomena observed for the Dutch situation. For simplicity we ignore the banking sector in the presentation below: the full model, including a banking sector, is presented in Meijers et al. (2015b) - MMS2 from hereon. Both in the latter model and in the presentation below, we use a simplified version of the household sector, in order to focus on the impact of firm behaviour.

After a review of the literature below, in Section 2 we present in more detail the stylised facts for the Dutch economy discussed above. In Section 3 we present the model. However, as is the case with most stock-flow consistent models, this model is still analytically intractable and its properties can only be analysed numerically. The model is analysed in Section 4 by means of numerical simulations. We show that this model can reproduce the stylised facts for the Netherlands, and demonstrate how adding a foreign sector and government enriches Hein's model considerably. Section 5 concludes.

\section{A survey of the literature}

The emergence of 'financialisation' of the non-financial corporate sector has been widely observed and discussed for the United States (Köhler 2014). A representative study is Orhangazi (2008), who analyses firm savings for the period 1973-2003 and observes the increased accumulation of financial assets in this sector. He points out two possible channels. The first channel is through increased profit opportunities in financial assets which crowd out real investment, because of increasing share buy-backs and dividend payments amongst other things. The increased use of share buy-backs - observed for instance by Evans (2015) - was induced by management incentives to increase share values and by tax facilities. The second channel is a shortening of the planning horizon and increasing uncertainty, as a consequence of participation in the financial markets these features impede real investment, which inherently has a longer-term horizon. The latter channel has been dubbed by Hein (2012) the 'preference channel'. Along with that, Hein also distinguishes the 'internal means of finance channel' according to which shareholders impose a more favourable distribution of profits on firms in order 
to pay out higher dividends. The first channel mentioned above is broader, since it also allows firms to accumulate financial assets. Although Hein ignores this accumulation of financial assets, we will use his terminology for this first channel since it is very much in the spirit of his analysis.

As we elaborate in MMS2, several studies have also observed a worldwide increase in financialisation of the non-financial corporate sector. However, there is only a limited literature on the macroeconomic implications of the increased financialisation of the non-financial corporate sector - see Toporowski (2009) for a broad overview of the social, economic and political consequences. For a model in the general equilibrium tradition, we refer to Bassetto et al. (2015), who also provide a summary of the relevant literature in that tradition.

Both Dos Santos (2005) and Michell/Toporowski (2011) argue that the financialisation should be analysed using stock-flow consistent models (SFC for short) - see also Muysken (2014). An important reason is that these models 'are based around the balance sheets of the various sectors of the economy, and incorporate detailed financial structure - thus considering explicitly the evolution of assets and liabilities and their associated money-flows' (Michell/Toporowski 2011: 30). Moreover, as Dos Santos (2005: 729) argues, '[c] ontrarily to the intuition of many, a relatively large SFC model is very often more transparent than ones that try to describe the behaviour of "economies as a whole" with a few equations. ... [O]ne should never underestimate the need to shed light on the implicit and "hidden" assumptions of these "parsimonious" models'.

Unfortunately there are only a few studies on firms' savings that adhere to the stockflow consistency tradition - for a detailed discussion, see MMS2. Several of these studies present a stock-flow consistent framework, but do not develop a macroeconomic model. An example is Passarella (2012), who only uses the budget identities of the SFC model, and builds a Minsky-inspired narrative around it. Michell (2014) presents a coherent agent-based SFC model in which firms use retained profits to finance investment in real capital. Although a strong point of the analysis is that it endogenises the distribution of firm sizes, a drawback of Michell's analysis from our perspective is that it ignores the two channels mentioned above through which financialisation has developed. Ryoo (2016) introduces an SFC model from a Kaldorian perspective where the profit share clears to adjust the goods market. A weak point in Ryoo's analysis is that the amount of equity issued by the firms is exogenous and real investment is determined by savings behaviour.

Our analysis is much closer to that of Hein (2012) and Caverzasi/Godin (2015). Hein (2012) develops a Kaleckian SFC model in which retained profits are endogenous and are used to finance retained earnings. A drawback of his model is that retained profits are not used to buy financial assets, except buy-backs of own shares. Thus Hein focuses on what is indicated by Köhler (2014: 14) as the 'passive dimension' of financialisation of firms and ignores the 'active dimension ... in which firms become agile performers on the financial market via financial investments reflected in a rise of their financial income'. As a consequence, the two channels that are distinguished above to explain financialisation are introduced in a quite artificial way. The 'preference channel' shows up as a decrease of the constant term in the investment function, representing 'animal spirits'. The 'internal means of finance channel' appears through the rentiers' rate of return, which is 'determined by the power struggle between managers and shareholders' (Hein 2012: 47), but appears as an exogenously determined variable in the investment function. An interesting aspect of Hein's model is that it can be solved in an analytical way, which is very rare for SFC models. We elaborate Hein's model in Section 3 below. 
Caverzasi/Godin (2015) present a Minsky-inspired SFC model that explicitly allows the use of retained profits to buy equity from other firms. These firms also hold deposits at banks as buffer stocks. The complexity of the model makes it difficult to analyse its properties carefully. ${ }^{1}$ However, an important element is that firms choose a growth rate for their outstanding assets driven by expected returns. On the one hand, this determines the expected need of external finance, since internal finance is found by subtracting the distributed profits, as a fixed share from total profits net of interest payments; equities then are issued as a fixed share of external finance and the remaining part is covered by loans from the banking sector. On the other hand, the outstanding assets then are distributed over physical capital and equity issued by other firms according to a Tobin portfolio model. The 'preference' channel then can be modelled as a change in the preference for physical capital relative to equity in the Tobin model; this causes inflation in the price of equities. The 'internal means of finance channel' is not explicitly recognised.

All the models we have discussed thus far are closed economy models. As a consequence, there is no potential relation between firm savings and the current-account balance, which we observe below for the Netherlands in Section 2. In an interesting paper, Kuzin/Schobert (2015) observe this relationship for Germany and present a simple SFC model to analyse it. They point out that retained profits have diminished the role for banks in financing real investment and as a consequence banks have turned to lending to foreign banks since

also retained profits need a source of financing. Export revenues of German firms are import expenditures abroad, which are financed by foreign credit to foreign non-banks. The funding for the foreign credit business increasingly took place abroad, but inside EMU. ... Financing conditions considerably eased with the start of the monetary union in EMU countries ... (Ibid.: 45)

These developments facilitated on the one hand the strong rise in the current-account surplus in Germany. On the other hand they increased the fragility of the financial system leading to its bail-out in Germany in 2008. Surprisingly enough, the SFC model that Kuzin/Schobert (2015) present to illustrate their story does not contain a firm sector. They present a two-country model of the EMU (North and South) with households, government and a consolidated banking sector, including the central bank. The banking sector issues deposits to households (high powered money) and absorbs government bills, both in their own country. Households also hold government bills. The adjustment mechanism is that 'surpluses in the North correspond to deficits in the South financed by issuing new central bank money. ... [which] leads to non-stationary balance sheet growth of the banking system' (ibid.: 48). However, there are no firms in their model, which makes the model rather unhelpful for our purpose.

In our analysis below we will take Hein's (2012) model as a point of departure, since it models the macroeconomic implications of firm savings in an analytically tractable way. However, we will allow the use of retained profits to buy financial assets abroad. The latter implies that we will also include a foreign sector. Finally, to allow for financial fragility, we will also add a banking sector. The full model will be presented in Section 3 below. But first, in Section 2, we present the relevant stylised facts of the Dutch economy.

1. The model includes, next to firms, two types of consumers, rentiers and workers, who both own houses; a housing market with exogenous supply but endogenous house prices; and finally a banking sector aiming for a targeted leverage ratio, providing credit to both firms and workers. Somewhat surprisingly, there is no government. 


\section{STYLISED FACTS}

In this section we present some stylised facts for the Netherlands, with a focus on savings and investments. ${ }^{2}$ In particular, we show that the majority of private savings are related to firms, in the form of retained profits. Moreover, firms increasingly use these retained profits for acquiring assets abroad instead of investing them domestically.

As we elaborate in MMS2, private savings in the Netherlands show an increasing gap relative to private investment. While private investment fluctuates relative to GDP, with a distinct negative trend since 2000, private savings have increased since the early 1980s. Government investment shows a negative trend over the whole period, decreasing from 7 per cent of GDP in 1970 to 4 per cent of GDP in 2012, while government savings are considerably lower. Private savings for households and firms initially developed parallel to each other in the same magnitude. However, after 1990 household savings fell, while firm savings increased. The fall in household savings can be explained by wage moderation and wealth effects on consumption of increasing house prices, as we elaborate in MMS1. The increase in firm savings follows from an increased preference for the retained profits of multinational corporations in the Netherlands, induced by low taxes and low dividend payments (Jansen/Ligthart: 2014). Investment of firms has been falling consistently since the mid 1980s; this is partly compensated by increasing investment of households. The latter led to a boom in the housing market, which collapsed in 2007, as we elaborate in MMS1.

As a consequence of these developments, net savings of firms have been increasing over time, albeit with fluctuations. Net savings of households were stable till 1990 and fell dramatically afterwards till 2007. Finally, government net savings fluctuated strongly procyclically, albeit with an increasing trend in the restoration period in the early 1980s, following the second oil crisis in 1979. These developments are illustrated in Figure 1. From that figure one also sees a remarkable feature, that household net savings and government net savings almost balance each other. The implication of this observation is that net savings of firms should be very close to net foreign savings, since the sum of net domestic savings and net foreign savings is by definition equal to zero. Not surprisingly this feature can be clearly observed in Figure 2 .

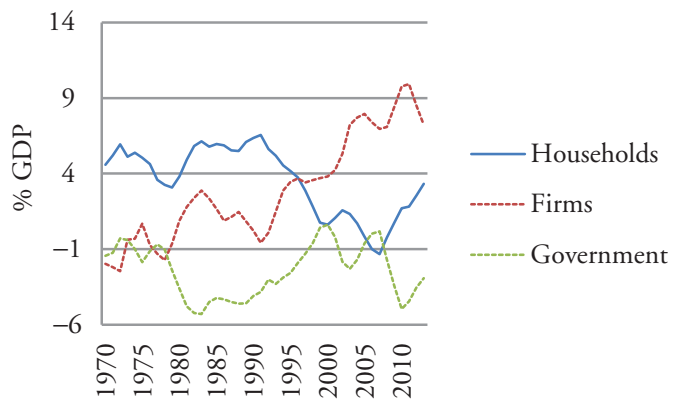

Source: AMECO.

Figure 1 Net savings of domestic sectors

2. This section relies on Bezemer/Muysken (2015). 


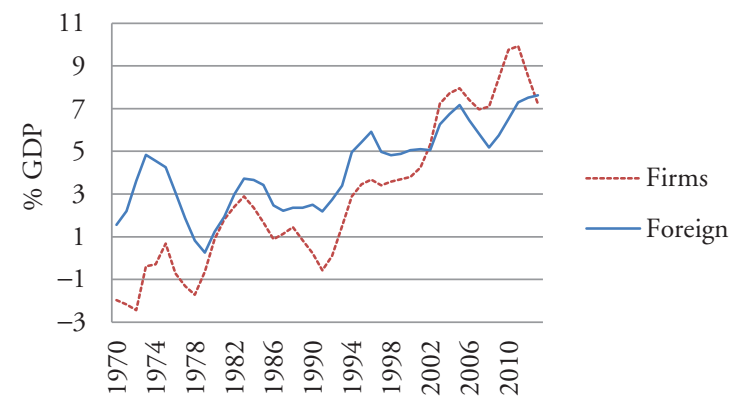

Source: AMECO.

\section{Figure 2 Firms' net savings and foreign net savings}

The observation that decreasing household net savings correspond to increasing government net savings can be explained on the one hand by the a-cyclical behaviour of consumption and the pro-cyclical behaviour of government deficits. Next to that, the increase in housing prices till 2008 induced lower net savings due to both wealth effects on consumption and increased investment in housing, which in turn also led to higher tax revenues. Finally tax incentives for the increasing number of (involuntary) self-employed persons also led to lower tax revenues. These trends are reversed after 2007.

Firm savings - that is, retained profits - are mainly concentrated at multinational corporations. These corporations also channel the profits of their foreign subsidiaries to the Netherlands for tax motives. As we elaborate in MMS2, the majority of these profits are not invested in the Netherlands, nor paid out as dividends, but are used to buy foreign assets, including take-overs. These assets generate a relatively high return, hence high profits (net of taxes), which then are used to accumulate more foreign assets (Eggelte et al. 2014). ${ }^{3}$ Through various channels this enables the foreign sector to borrow from the Netherlands in order to pay for their net imports - although the actual funding of the net imports by the rest of the world may be independent of the firms' decision to invest abroad. This explains the co-movement of net savings of firms and foreign net savings, depicted in Figure 2.

The observations in Figures 1 and 2 also constitute the main stylised facts we want to analyse in our model:

1. The decrease in household net savings, prior to 2007, accompanied by an increase in government net savings, and the reversal of these trends thereafter;

2. The increase in net firm savings, accompanied by an increase in net foreign savings.

\section{A STOCK-FLOW CONSISTENT MODEL WITH SAVINGS BY FIRMS FOR THE DUTCH ECONOMY}

The stock-flow consistent model for the Dutch economy is inspired by Hein (2012) as far as the modelling of firm and consumer behaviour is concerned. Since we want to analyse the impact of the possibility of firms to invest part of their profits in foreign assets in relation to

3. About 75 per cent of the shares of multinationals in the Netherlands are owned by nonresidents - the comparable figures in Germany and France are less than half of the Dutch share (Eggelte et al. 2014). 
the current account, we extend the analysis to an open economy context and also include government. In Section 3.1 we present a model of firm behaviour where we extend Hein's model to allow for investment of retained profits in foreign assets. In Section 3.2 we introduce household behaviour, distinguishing between workers and rentiers. In Section 3.3 we introduce the foreign sector and in Section 3.4 the government sector. These last two sections are based on our earlier analysis presented in MMS1. Finally, a summary of the stock and flow relations of the model is presented in Section 3.5. A more elaborated version of this model, also including a financial sector, is presented MMS2.

\subsection{Firm behaviour and foreign investment}

We extend Hein's model on firm behaviour to allow for investment of retained profits in foreign assets and to finance investment by borrowing from abroad. The latter implies that the capital stock $(p . K)$ is financed by firms using a part $\left(E_{f}\right)$ of their domestically accumulated retained earnings, next to equity issued to rentiers $\left(E_{r}\right)$ and loans abroad $\left(B_{f a}\right){ }^{4}$ Firms hold the other part of their retained earnings in foreign equity $\left(E_{a}\right)$ - the prices of both types of equity are assumed to be fixed at an exogenously determined level; for that reason they are not included explicitly in the model. The net worth of firms is $V_{f}=p . K-E_{f}+E_{a}-B_{f a}$; see also the balance sheet of firms presented in Table 1.

Retained earnings follow from profits. Profits from production $F_{P}$ result by deducting the wage bill $w . N$ from nominal income $p . Y$. Hence:

$$
F_{P}=p \cdot Y-w \cdot N \text {. }
$$

Nominal wages $w$ are exogenous. ${ }^{5}$ Given the exogenous labour-output ratio $a$, employment $N$ follows from $N=a . Y$, where $Y$ represents real output. Price $p$ is set as a mark-up $m$ on unit labour cost $w \cdot a$. Hence:

$$
p=[1+m] \cdot w \cdot a \text {. }
$$

Substitution of equation (2) in equation (1) shows that a positive mark-up guarantees positive profits. ${ }^{6}$

Table 1 Balance sheet

\begin{tabular}{lccccc}
\hline & Rentiers & Firms & Government & Foreign & Total \\
\hline Bills & $+B_{g r}$ & - & $-B_{g r}-B_{g a}$ & $+B_{g a}$ & 0 \\
Capital & - & $+p \cdot K$ & - & - & $+p \cdot K$ \\
Equities & $+E_{r}$ & $+E_{a}-E_{r}$ & - & $-E_{a}$ & 0 \\
Bonds & - & $-B_{f a}$ & - & $+B_{f a}$ & - \\
Total (net worth) & $+V_{r}$ & $+V_{f}$ & $+V_{g}$ & $+V_{a}$ & $+V_{t}$ \\
\hline
\end{tabular}

4. In the extended version of our model, banks intermediate in borrowing from abroad - see MMS2.

5. We ignore in this version of the model the determination of unemployment and its potential interaction with wage determination and social security expenditures. That is left for further research.

6. Hein assumes a positive impact of the rate of return on equity $\rho$ on the mark-up, that is: $m^{\prime}(\rho)>0$. We leave this out, for simplicity. 
When calculating total profits $F_{T}$, we should include the returns on foreign equity $E_{a}$, next to profits from production $F_{P}$. The rate of return on foreign equity $\rho_{a}$ is exogenously determined. Hence:

$$
F_{T}=F_{P}+\rho_{a,-1} \cdot E_{a,-1}=\text { m.w.a. } Y+\rho_{a,-1} \cdot E_{a,-1} .
$$

Part of the total profits is kept as retained earnings, which constitute firm's savings $S_{f}$; the remaining part is paid out as dividend or interest payments. Retained earnings therefore are given by:

$$
S_{f}=F_{T}-\rho_{r,-1} \cdot E_{r,-1}-i_{f a,-1} \cdot B_{f a,-1},
$$

where $i_{f a}$ represents the rate of interest on bonds issued abroad $B_{f a}$, and $\rho_{r}$ is the return on equity $E_{r}$ issued to rentiers; both $i_{f a}$ and $\rho_{r}$ are exogenously determined.

The firm's savings $S_{f}$ (retained earnings) are not set as a fixed proportion of total profits, as in MMS1 amongst others, ${ }^{7}$ but follow from the decisions on debt formation in the past and exogenous interest rates and dividends - as can be seen from equation (4).

In Hein's model, a firm's savings are solely used to finance the capital stock. However, as we have seen in Section 2, firms also invest their savings in foreign assets. Hence we have:

$$
S_{f}=\Delta E_{f}+\Delta E_{a} .
$$

Inspired by Tobin's portfolio model, we model the distribution of a firm's savings over foreign equity and investment in capital as dependent on the rates of return of both. ${ }^{8}$ Hence the share of retained earnings invested abroad $s_{f a}=\Delta E_{a} / S_{f}$ is given by:

$$
s_{f a}=\lambda_{0}-\lambda_{1} \cdot r+\lambda_{2} \cdot\left(\rho_{a}-i_{f a}\right) .
$$

The return on capital $r$ follows from $r=F_{P} / p K$ - we exclude returns on foreign investment from total profits, since the remaining part of profits is attributable to investment in capital.

In line with Hein's analysis, gross investment is determined by four variables. First, management's animal spirits, represented by a coefficient $\theta_{0}-$ a higher value will lead to more investment. ${ }^{9}$ The second variable is the utilisation rate $u=Y / Y^{p}$, where $Y^{p}$ stands for potential output, which is related to capital by the capital-output ratio $\kappa$, such that $K=\kappa \cdot Y^{p}$. The utilisation rate is considered relative to normal utilisation $u^{*}-$ see also Zezza (2008) and MMS1. The third variable is the domestic profit share $h=F_{P} / p Y-$ again we exclude returns on foreign investment since the remaining part of profits is attributable to investment in capital. Obviously, a higher utilisation rate and a higher profit share will lead to higher investment. Finally, investment is negatively influenced by the costs of

7. Caverzasi/Godin (2015) also assume that a fixed share of profits is retained, but in addition to that they explicitly recognise capital gains as a component of a firm's savings.

8. A similar approach has been followed by Caverzasi/Godin (2015). However, in their model firms are allowed to attract funds in excess of firm's savings to invest in financial assets. The decision on asset accumulation is taken independent of the decision of asset allocation. As equations (6) and (7) show, these two decisions are not independent in our model, which seems more plausible. In equation (6) the rate of return on foreign equity $\rho_{a}$ is taken net of $i_{f a}$, the rate of interest on bonds issued abroad $B_{f a}$, since investing less in foreign equity implies that less has to be borrowed abroad to finance investment (more internal funds are available). In equation (7) the share of external funding negatively influences investment (less internal funds are available).

9. We also allow for depreciation, which reduces the value of $\theta_{0}$. 
external funding, represented by $\gamma \cdot \rho_{r}$ where $\gamma=\left(E_{r}+B_{f a}\right) / p K$ is the share of external funding of investment. ${ }^{10}$ Therefore we find:

$$
g=I / p \cdot K=\theta_{0}+\theta_{1} \cdot(u-u *)+\theta_{2} \cdot h-\theta_{3} \cdot \gamma \cdot \rho_{r} .
$$

Gross investment is financed by domestically retained earnings $\Delta E_{f}=\left(1-s_{f a}\right) \cdot S_{f}$, equity issued to rentiers $\Delta E_{r}$ and bonds issued abroad $\Delta B_{f a}$. As we elaborate below, rentiers are willing to hold a certain amount of equity at the rate $\rho_{r}$. Since we assume that firms are willing to issue this amount of equity in order to finance investment, $\Delta E_{r}$ is given for firms as a source of finance of their investments. ${ }^{11}$ As a consequence, firms will borrow the remaining funds needed for investment by issuing bonds abroad, hence:

$$
\Delta B_{f a}=p \cdot \Delta K-\left(1-s_{f a}\right) \cdot S_{f}-\Delta E_{r} .
$$

\subsection{The behaviour of households}

Regarding households, we distinguish between rentiers and wage earners. Moreover, in line with Hein, we ignore for simplicity the presence of housing and pension wealth. The impact of these latter two factors on household behaviour is elaborated extensively in MMS1.

Wage earners consume all of their disposable income, which consists of the wage bill $w . N$, net of taxes at a rate $\tau_{d}$. Hence wage earners do not save and do not hold wealth. Only rentiers hold wealth, which is either in the form of government bonds $\left(B_{g r}\right)$ or in the form of equity issued by firms $\left(E_{r}\right)$. The resulting balance sheet of rentiers is presented in Table 1 .

In line with the literature - see MMS1 for a survey - demand for equity $E_{r}$ and bonds $B_{g r}$ follows from a Tobin-type portfolio model. ${ }^{12}$ Rentiers wealth $V_{r}$ is distributed over its assets components as follows: ${ }^{13}$

$$
\begin{gathered}
E_{r} / V_{r}=\mu_{0}-\mu_{1} \cdot i_{g r}+\mu_{2} \cdot \rho_{r} \\
B_{g} / V_{r}=1-E_{r} / V_{r} .
\end{gathered}
$$

Here $i_{g r}$ refers to the interest on government bonds and $\rho_{r}$ the return on equity issued by firms.

The disposable income of rentiers $Y_{r d}$ follows from interest income on government bonds and dividend income from firms, both net of taxes at a rate $\tau_{d}$, hence:

$$
Y_{r d}=\left(1-\tau_{d}\right) \cdot\left(i_{g r,-1} \cdot B_{g r,-1}+\rho_{r,-1} \cdot E_{r,-1}\right) .
$$

10. Strictly speaking the rate of return $\rho_{r}$ only refers to equity financing, while the rate of interest on bonds, $i_{f a}$, should also be taken into account. However, we use only $\rho_{r}$ for simplicity - when $\rho_{r}$ is endogenous, this assumption can no longer be maintained.

11. If firms would use retained profits to buy back equity $\Delta E_{r}$ could be negative, we will elaborate this option in a next version of the model. The same holds for including equity prices in the model, which then can be used to clear the equity market instead of assuming that all equity rentiers wish to hold at an exogenous price is issued by the firms.

12. Hein essentially assumes that households only hold equity as assets and therefore does not model any portfolio decisions.

13. We ignore expectations here, but in a more elaborate version of the Tobin model - see, for instance, Godley/Lavoie (2007a), Zezza (2008) and MMS1 - demand for assets depends on expected returns, and demand for deposits then adjusts for mistakes in expectations, while expected demand for equity is realised. 
Rentiers savings are assumed to be a fraction $s_{r}$ of disposable income of households $Y_{r d}$ :

$$
S_{r}=s_{r} . Y_{r d}
$$

The accumulation of rentiers' wealth $\Delta V_{r}$ follows from savings $S_{r}$ by rentiers; these savings are invested in either government bonds or equity, in line with equations (9) and (10):

$$
S_{r}=\Delta B_{g r}+\Delta E_{r}
$$

\subsection{The foreign sector}

The foreign sector is introduced in a simple way, following Godley/Lavoie (2007b) and MMS1. Next to consumption, investment and government goods, firms also produce net exports $(X-I M)$. This does not affect their balance sheet, however, nor does it affect their flow of funds. We assume exports $X$ to be exogenous and imports $I M$ to be proportional to GDP with a fraction $i m$. Hence the trade balance is given by:

$$
T B=X-I M=X-i m \cdot p . Y .
$$

Initially Godley/Lavoie do not discuss terms of trade and exchange-rate issues. Here, we follow their ignorance of these issues - partly motivated by the knowledge that a lot of trade by the Netherlands is within the euro area.

Next to bonds held by firms $\left(B_{f a}\right)$, foreigners hold bonds issued by government $\left(B_{g a}\right)$ : both appear as assets in the balance sheet of the foreign sector. The liabilities of the foreign sector consist of foreign equity held by domestic firms $\left(E_{a}\right)$. The balance sheet of the foreign sector is given in Table 1 .

The trade balance is part of foreign savings $S_{a}$, together with dividends paid to domestic firms on their foreign investment $\rho_{a}$. $E_{a}$ and interest received on firm and government bonds by the foreign sector:

$$
S_{a}=i_{f a,-1} \cdot B_{f a,-1}+i_{g a,-1} \cdot B_{g a,-1}-T B-\rho_{a,-1} \cdot E_{a,-1} .
$$

Negative foreign savings imply net lending abroad and decrease total net worth abroad $\left(V_{a}\right)$ :

$$
\Delta B_{g a}+\Delta B_{f a}-\Delta E_{a}=-S_{a} .
$$

As Godley/Lavoie (2007b) emphasise, there is no inherent mechanism for a country with a trade surplus to converge to a balanced current account, as long as it is willing to accumulate ever-more foreign debt. This situation is quite relevant for the Netherlands, as is elaborated in MMS1.

\subsection{The government}

Government expenditures $G$ are proportional to output, in line with MMS1. As a consequence, growth in government expenditures is equal to output growth: $g_{G}=g_{p . Y,-1}$. Taxes are proportional to the relevant bases as we discussed in Section 3.2. The budget balance, minus interest paid on government bonds, constitutes government savings $S_{g}$ :

$$
S_{g}=\tau_{d} \cdot\left(w \cdot N+i_{g r,-1} \cdot B_{g r,-1}+\rho_{r,-1} \cdot E_{r,-1}\right)-p \cdot G-i_{g r,-1} \cdot B_{g r,-1}-i_{g a,-1} \cdot B_{g a,-1} .
$$


These savings, which are usually negative, are financed by issuing bonds:

$$
\Delta B_{g r}+\Delta B_{g a}=-S_{g} .
$$

Accumulated government debt therefore equals $B_{g r}+B_{g a}$, which is also the negative financial net worth of government.

\subsection{The structure of the full model}

The model is summarised in Table 1, which presents the balance sheets of the various sectors. Since savings of each sector add to the net worth of that sector, Table 1 shows which types of assets savings are invested in - consistent with equations (5), (13), (16) and (18) for firms, rentiers, abroad and government, respectively.

Another way of looking at the model is presented in the social accounting matrix Table 2, which presents a consistent schedule of all flows between sectors. For instance, Table 2 shows for each sector how the savings have been accumulated-consistent with equations (4), (12), (15) and (17) for firms, rentiers, abroad and government, respectively. The full model is presented in MMS2, appendix A.

Hein's model could be solved analytically. However, as we explain in MMS2, because we allow firms to invest in foreign assets next to domestic capital, the model can no longer be solved analytically and we have to resort to numerical analysis to further analyse the properties of the model. This is the topic of the next section.

\section{THE SIMULATION RESULTS}

In the base run of the numerical analysis of the model presented above, we assume an exogenous growth of exports of 5 per cent and no productivity growth. The parameter values are chosen to reflect the Dutch situation in those cases for which information was available. However, the parameter values of the behavioural equations of firms (investment function and share of assets abroad) and of rentiers (portfolio model) have been calibrated to find a reasonable outcome. Moreover, data on the various types of wealth have also been calibrated. The simulation results are quite sensitive to the initial values of wealth. For that reason we would like to emphasise that the base run of the model does not fully describe a steady state but leads to constant growth rates for most of the important variables. Since the simulation results are presented relative to the base run, they illustrate the working of the model and lead to some interesting insights.

After initial fluctuations, the base run shows an output growth of 5 per cent from period 1000 onwards, ${ }^{14}$ a government deficit of 2 per cent of GDP and a trade balance surplus fluctuating between 1 and 4 per cent of GDP. Unfortunately the share of external funding in investment, $\gamma$, is not stable but declining slowly. This implies that we are not in the steady state described by Hein (2012).

We simulated two shocks to the model, both affecting the share of retained earnings abroad $s_{f a}$. This share is given by equation (6) above, which we reproduce here:

$$
s_{f a}=\lambda_{0}-\lambda_{1} \cdot r+\lambda_{2} \cdot\left(\rho_{a}-i_{f a}\right) .
$$

14. This is not primarily due to the export growth of 5 per cent. Also for lower rates of export growth the model shows a growth rate of output of 5 per cent. 


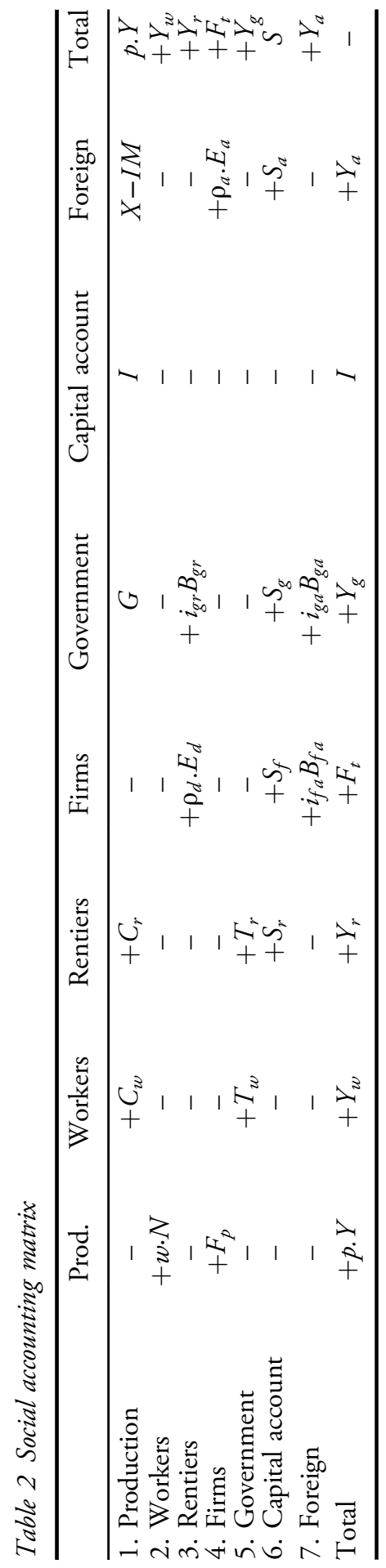


A higher return on capital $r$ leads to more investment of retained earnings in physical capital; a higher rate of return on foreign equity $\rho_{a}$ implies more investment of retained earnings in foreign assets.

Our first simulation is an increase in the affinity to invest abroad (animal spirits), $\lambda_{0}$, for the period 1030-1100. This will increase $s_{f a}$ over that period. As a contrast, we investigate in our second simulation the impact of an increase in the rate of return on foreign equity, $\rho_{a}$, for the period 1030-1100. This will also increase $s_{f a}$ over that period. The impact of both shocks to output growth and investment growth are presented in Figure 3a.

As one might expect, the increased affinity to invest abroad leads to lower investment since a higher share of retained earnings is invested abroad. The latter increases the share of outside financed capital, which has a negative impact on investment - cf. equation (7). This also leads to lower GDP growth. Moving to the second simulation, depicted in Figure $3 \mathrm{~b}$, it is therefore at first sight surprising to find that an increase in the rate of return on foreign equity, which also increases the share of retained earnings invested abroad, leads to higher investment and GDP growth. The reason is that total profits also increase - see equation (3) above - because of a higher income from foreign assets. These increased profits are partly used to finance investment and thus reduce the need for outside financed capital, leading to an increase in investment. This is also illustrated in Figure 4. From Figure 4a one sees that following an increased affinity to invest abroad, the share of external funding in investment has increased. The reason is that fewer retained profits are available for investment; hence more external funding is required. However, as can be observed from Figure $4 \mathrm{~b}$, this is does not happen in the case of an increased return in foreign equity, because retained profits have increased.

As one might expect in both cases, the net lending of firms abroad has increased because of the increased share of retained profits invested abroad. The impact is much stronger in the case of increased return on foreign equity (see MMS2, fig. 13b), because the share of retained profits has increased as well as the retained profits themselves. Interestingly enough, net lending abroad mimics the net lending of firms in both cases, which is consistent with the stylised fact we observed for the Netherlands. ${ }^{15}$ One should also realise that in both

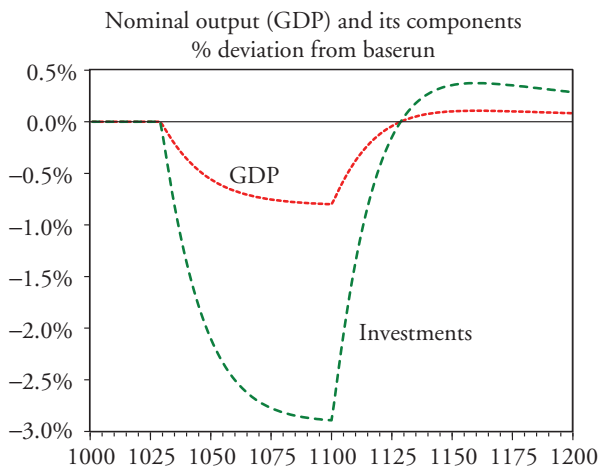

(a) Increased affinity to invest abroad

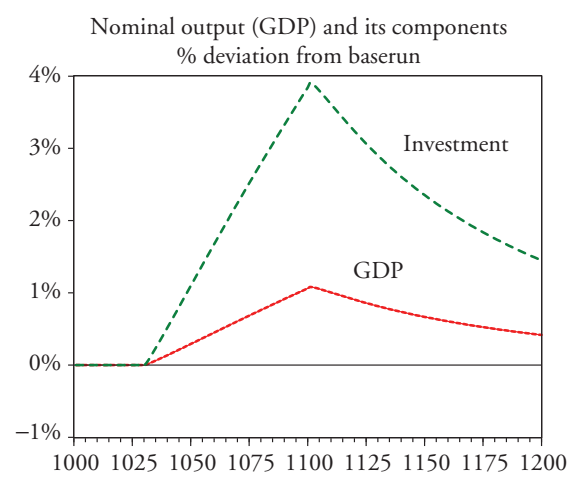

(b) Increased return on foreign equity

\section{Figure 3 Output and investment growth}

15. This can also be understood when one considers the net firm savings as defined implicitly in equation (8), which are $S_{f}-I=+\Delta E_{a}-\Delta B_{f a}-\Delta E_{r}$. The net savings abroad are $-S_{a}=+\Delta E_{a}-\Delta B_{f a}-\Delta B_{g a}-$ see also equation (16). 

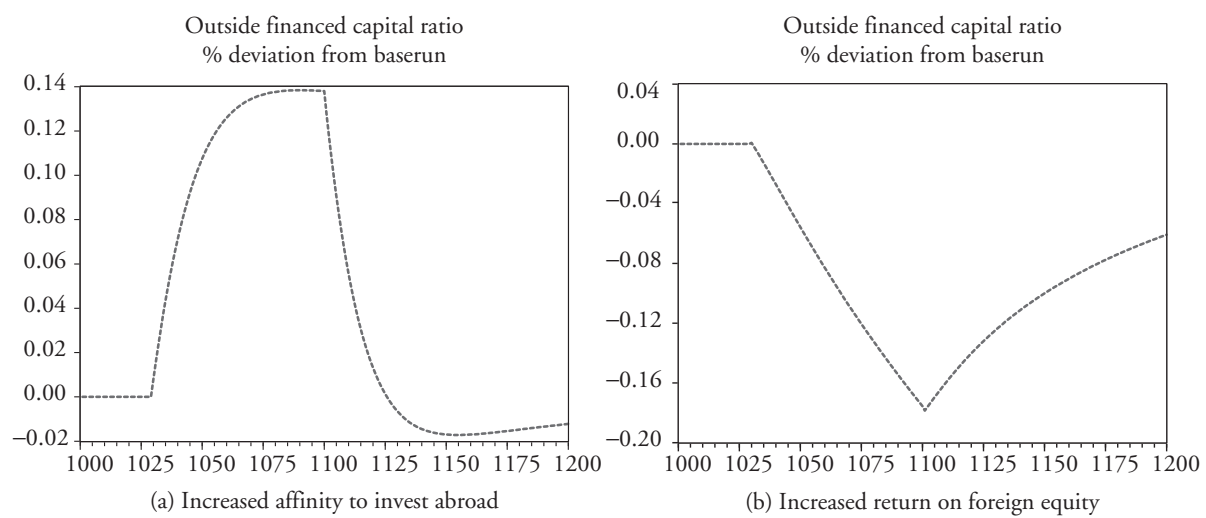

Figure 4 Share of external funding in investment

cases net lending abroad increases, although the balance of trade moves in opposite directions in line with the movement of GDP. To understand this latter phenomenon, we reproduce net lending abroad from equation (15):

$$
-S_{a}=T B+\rho_{a,-1} \cdot E_{a,-1}-i_{a,-1} \cdot B_{f a,-1}-i_{a,-1} \cdot B_{g a,-1} .
$$

Since in the first simulation GDP decreases, the trade balance increases and net lending abroad increases. In the second simulation, GDP increases and hence the trade balance decreases. However, net lending abroad increases because the returns on foreign investment, $\rho_{a,-1} . E_{a,-1}$, increase more strongly than the decrease in the balance of trade.

\section{CONCLUDING REMARKS}

We observed for the Dutch economy that net private savings have increased over time. However, contrary to popular belief, this is not due to a strong inclination to save by Calvinistic households, but due to increased retained profits by firms which are invested abroad instead of in physical capital domestically. To explain this phenomenon, we have developed a stock-flow consistent model to incorporate the notion that firms invest a considerable part of their retained profits abroad. This model can also be used to explain the stylised fact for the Netherlands that net savings of firms move closely in line with net foreign savings.

The simulation results with the model show that the presence of a considerable amount of foreign assets held by firms can lead to large capital inflows, compensating the capital outflows due to a balance-of-trade surplus. However, we have also learned from the simulation experiments that a more careful calibration of the model is needed to obtain a complete steady-sate solution in the base run. That is left for further research. Moreover, the current model has been simulated while ignoring the interaction with the financial sector. Incorporating the financial sector in the simulation is another challenge left for further research - see also MMS2. This holds in particular for extending the model to endogenise the rate of returns on equity and the interest rates on the financial markets. 


\section{REFERENCES}

Bassetto, M., Cagetti, M., De Nardi, M. (2015): Credit crunches and credit allocation in a model of entrepreneurship, in: Review of Economic Dynamics, 18, 53-76.

Bezemer, D., Muysken, J. (2015): Financialization and the financial and economic crises: the case of the Netherlands, FESSUD Studies in Financial Systems, No 33, May.

Caverzasi, E., Godin, A. (2015): Financialisation and the sub-prime crisis: a stock-flow consistent model, in: European Journal of Economics and Economic Policies: Intervention, 12(1), 73-92.

Dos Santos, C. (2005): A stock-flow general consistent framework for formal Minskian analyses of closed economies, in: Journal of Post Keynesian Economics, 27(4), 711-735.

Eggelte, J., Hillebrand, R., Kooiman, T., Schotten, G. (2014): Het nationale spaaroverschot ontleed, in: Occasional Studies, 12(6), 1-62.

Evans, T. (2015): Factors generating and transmitting the US financial crisis: overview paper, FESSUD Working Paper Series No 45, University of Leeds.

Godley, W., Lavoie, M. (2007a): Monetary Economics: An Integrated Approach to Credit, Money, Income, Production and Wealth, London: Palgrave Macmillan.

Godley, W., Lavoie, M. (2007b): A simple model of three economies with currencies: the Eurozone and the USA, in: Journal of Economics, 31, 1-23.

Hein, E. (2012): The Macroeconomics of Finance-Dominated Capitalism - and its Crisis, Cheltenham, UK and Northampton, MA: Edward Elgar.

Jansen, C., Ligthart, M. (2014): Spaaroverschot niet-financiële bedrijven: ontwikkeling, oorzaken en gevolgen, in: CPB Achtergronddocument, Den Haag: Centraal Planbureau.

Köhler, K. (2014): Dimensions of financialisation and their impact on functional income distribution, Paper presented at the Herodox Economics Conference, Berlin, October.

Kuzin, V., Schobert, F. (2015): Why does bank credit not drive money in Germany (any more)?, in: Economic Modelling, 48, 41-51.

Meijers, H., Muysken J., Sleijpen, O. (2015a): The deposit financing gap: another Dutch disease, in: European Journal of Economics and Economic Policies: Intervention, 12(1), 32-50.

Meijers, H., Muysken, J., Sleijpen, O. (2015b): Firms' excess savings and the Dutch current account surplus: a stock-flow consistent approach, UNU-Merit Working Paper series 2015-040.

Michell, J. (2014): A Steindlian account of the distribution of corporate profits and leverage: a stockflow consistent macroeconomic model with agent-based microfoundations, Working Paper, Post Keynesian Economics Study Group (PKSG).

Michell, J., Toporowski, J. (2011): The stock-flow consistent approach with active financial markets, in: Papadimitriou, D., Zezza, G.(eds), Contributions to Stock-Flow Modelling: Essays in Honor of Wynne Godley, Basingstoke, UK: Palgrave Macmillan, 173-196.

Muysken, J. (2014): Macroeconomics beyond general equilibrium, in: Merbis, M., van Wesenbeek, L. (eds), Real and Integer: Thirty Essays on Economics, Development and Michiel Keyzer, Amsterdam: SOW-VU, 9-29.

Orhangazi, Ö. (2008): Financialisation and capital accumulation in the non-financial corporate sector: a theoretical and empirical investigation on the US economy: 1973-2003, in: Cambridge Journal of Economics, 32, 863-886.

Passarella, M. (2012): A simplified stock-flow consistent dynamic model of the systemic financial fragility in the 'New Capitalism', in: Journal of Economic Behavior \& Organization, 83(3), 570-582.

Ryoo, S. (2016): Inequality of income and wealth in the long run: a Kaldorian perspective, in: Metroeconomica, 67(2), 429-457.

Toporowski, J. (2009): The economics and culture of financialization, in: Competition \& Change, 13(2), $145-156$.

Zezza, G. (2008): U.S. growth, the housing market and the distribution of income, in: Journal of Post Keynesian Economics, 30(3), 375-401. 